\title{
The Amber Road: Cross-Border Trade and the Regulation of the Burmite Market in Tengchong, Yunnan
}

\section{Alessandro Rippa' and Yi Yang ${ }^{2}$}

\begin{abstract}
This paper investigates the new and hitherto unstudied boom in cross-border Burmese amber (Burmite) trade between Myanmar and Tengchong, Yunnan province. Based on interviews with amber dealers and local officials, it describes how since 2012-13 the amber trade has become increasingly lucrative for Chinese and Myanmar traders, and has attracted a large number of people to Tengchong, which, within Yunnan, virtually monopolises the trade. After a brief historical introduction, the paper analyses the conditions that, in both countries, have made the Burmite trade boom possible. It further describes the current composition of the amber market in both Myanmar and China, before analysing recent attempts to monitor and regulate the amber trade through the institution of the Tengchong Amber Association by the city's main amber traders in collaboration with local authorities.
\end{abstract}

KEYWORDS: Amber, China, Myanmar, border trade, shadow economies

\section{INTRODUCTION}

$\mathrm{T}$ ENGCHONG IS A COUNTY-LEVEL city of Baoshan prefecture, western Yunnan, which shares a $151 \mathrm{~km}$ long border with Myanmar's Kachin state. Previously known as Tengyue (腾越), due to its specific geographical location along one of the main trading routes between China, India, and South-East Asia, Tengchong has a long history as an administrative, military, and trading outpost (Fang 2010; Yin and Ma 1991). Following the establishment of the People's Republic of China (PRC) in 1949 and Myanmar's independence in 1948, several factors contributed to a significant decrease in cross-border economic relations. Particularly, China's covert support for the Communist Party of Burma (CPB) seriously compromised the two countries' relations, and although local trade survived (Lintner 2011 [1990]) even in communist-held areas, dramatic changes emerged only after the Myanmar military coup in 1988 when the two countries began to strengthen their

\footnotetext{
${ }^{1}$ Alessandro Rippa, Department of Social and Cultural Anthropology, Ludwig-Maximilians-Universität München, Germany; alessandro.rippa@lmu.edu.

${ }^{2}$ Yi Yang, Institute of Anthropology, East China Normal University.
} 
political and strategic ties. Since the 1990s, China and Myanmar's economic relations have gradually improved, and cross-border trade has grown significantly; it now accounts for about 70 per cent of Myanmar's total border trade (Kudo 2008; 2010).

With the normalisation of the two countries' relations, three official border crossings have been established in Tengchong county alone: Houqiao (猴桥口岸), a national-level border port since 2004, Diantan (滇滩口岸), and Zizhi (自治口岸). As recently shown by anthropologist Zhou Yongming (2013), local authorities are putting a lot of effort into trying to establish Tengchong as the crucial node - or, as in the official rhetoric, a "bridgehead" (qiaotoubao 桥头堡) - for China-Myanmar trade. ${ }^{1}$ The flagship project, in this regard, is certainly the reconstruction of the Stillwell Road to Myitkyina in Myanmar's Kachin state and Assam state in India. The Stillwell Road - also known as Ledo Road - was built by the Chinese, Indian, and American forces during the Second World War as a supply route for Chiang KaiShek's troops fighting the Japanese army in Yunnan. Today, the new Stillwell Road runs from Tengchong to the Houqiao port, where a new trade centre is currently under construction, while plans for its extension further into Myanmar and India are still under negotiation. Plans for the development of cross-border trade in the area are, however, much more ambitious. Through the 'One Belt One Road (yidai yilu 一带一路)' initiative, China is currently extending the newly built Baoshan-Tengchong highway to Houqiao, and from there to Myitkyina. Often branded as the BangladeshChina-India-Myanmar (BCIM) Economic corridor, the long-term objective of this project is to tie those countries together through a network of infrastructure (Anonymous interview, 30 January 2016).

In Tengchong - which has only recently, in 2015, been elevated to the status of a county-level city (xianji shi 县级市) - these various projects brought fast growth and large investments, and the small city is thriving with activities in one way or another connected to cross-border trade. The content of this trade is, however, changing, with new commodities entering the market marginalising others. One such commodity is Burmese amber, also known as Burmite.

This paper investigates the new and hitherto unstudied boom in the crossborder amber trade between Myanmar and Tengchong, based on interviews with amber dealers and local officials collected over five visits to Tengchong county between 2015 and 2016, and one visit to Myitkyina in 2015. Interviews in Tengchong were carried out as part of a larger project on Chinese borderlands rooted in ethnographic research, and thus, the focus of this paper is on the amber market on the Chinese side of the border. Furthermore, the area where the amber mines are located within Myanmar is currently not

\footnotetext{
${ }^{1}$ Fang I-chieh (2010) noticed that in 2001 the Tengchong government was already trying to develop its tourist business, labelling the city as a "[c]ulturally prosperous border country," thus playing the card of Tengchong's proximity to the border and its traditional role as a trading hub.
} 
accessible to foreign researchers, making it impossible to obtain a clear picture of how amber is extracted and brought to Myitkyina. On both sides of the border, moreover, the complete lack of official data on the trade made it very difficult to verify some of the claims made by our interviewees. All data presented in this paper has been cross-checked with various actors, and we are thus confident it offers a reliable overview of the current status of the Burmite trade. ${ }^{2}$

The main aim of this study is that of offering a first assessment of the current boom in the Burmite trade in Tengchong, and of the on-going attempts to regulate it on the Chinese side of the border. In order to do so, the paper moves from a discussion of the literature on cross-border trade and the shadow economy, to the aim of highlighting the role of the state in such processes, particularly through collaboration with private entrepreneurs in the regulation of the trade itself. Then, after a brief historical introduction, the paper analyses the economic and political conditions in both Myanmar and China that allowed for the trade to grow tremendously since the early 2010s. In the second part, relying on ethnographic material, we describe the current composition of the amber markets in Myitkyina and Tengchong, as well as recent attempts to monitor and regulate the amber trade through the institution of the Tengchong Amber Association by the city's main amber traders in collaboration with local authorities. Although amber is sold legally in Tengchong, in most cases it is transported illegally into the country, generating ambiguities and potential conflicts that both local dealers and authorities are attempting to fix. The Tengchong case thus offers novel insights into the on-going discussion over the role of state and market forces in China, as well as into the ways illicit markets are regulated in the wake of the One Belt, One Road (OBOR) Initiative. Finally, in the conclusion we analyse some of the possible challenges that the amber trade might face in the near future.

\section{BORDER TRADE, THE STATE, AND THE SHADOW ECONOMY}

Inquiries into illicit economies have often looked at borderlands as prominent spaces of lawlessness and shadowy exchanges (Galemba 2013; Bruns and Miggelbrink 2012; Chouvy 2013). Far removed from the centres of power, borders seem

\footnotetext{
${ }^{2}$ Our main interviewees were ten of the largest Tengchong-based traders involved in the amber business, with whom we spoke several times during each visit. Two local officials involved in the regulation of the amber trade were also regularly interviewed. Besides them, we spoke at least once with over fifty small-scale amber traders (both Chinese and Burmese) in Tengchong and Myitkyina. As mentioned, the research is based on long-term ethnographic fieldwork, and all data included in this paper were cross-checked with different actors (traders, border guards, local businessmen, etc.) whom, although not always directly involved with the amber trade, possess comprehensive knowledge of cross-border practices in the area. Given the nature of the research, they cannot be numbered and classified with precision.
} 
to carry the burden of remoteness that allows for such unlawful economies to prosper, yet at the same time represent the very core of the nation by defining its precise geo-body (Winichakul 1994). Borders, even when strictly enforced, seem to remain ultimately unmanageable and uncontrollable. Borders, moreover, are often characterised by marked economic differentials which, in turn, afford those involved in both licit and illicit trade countless opportunities (Saxer 2009, 2016; Alff 2016c). One of the main contributions anthropologists have made to this body of literature in recent years lies in the realisation that, however illicit or illegal such economies might be, they can be extremely formalised, often operating along kinship networks (Steenberg 2014; van Spengen 2000) and ethnic identities (Eilenberg and Wadley 2009; Schoenberger and Turner 2009) that span across national boundaries.

Besides its contextual value, the case of the on-going regulation of the amber trade in Tengchong analysed in this paper offers interesting insights to the literature on cross-border trade and so-called informal or shadow economies. As Nordstrom (2000) reminds us, 'shadow networks' are not just often formalised through specific hierarchies, but also follow specific rules of conduct. This clearly brings into question the idea that shadow exchanges are primarily motivated by the desire to escape regulation - in most cases dictated by nation states. Anthropologists and other social scientists, moreover, have invited scholars to look beyond the state in the analysis of such practices (Abraham and van Schendel 2005; Gootenberg 2005), showing how the state is often directly involved with such traffic on different levels and scales (To, Mahanty, and Dressler 2014).

The Tengchong case presented in this paper is interesting for at least two reasons. First, it shows how the state can complicitly participate in the creation and maintenance of these (shadow) networks. Chinese authorities in Tengchong were aware from the very beginning of the trading of amber illegally brought into the country and then openly sold in town. Yet understanding the potentiality for the further development of the trade and its positive impact on the overall economy of Tengchong, they consciously decided not to intervene - a situation which clearly contradicts views of the shadow economy as harmful to the formal economy and mostly due to weak regulatory institutions (Schneider and Enste 2002). Thus, following Abraham and van Schendel's (2005) famous distinction, the trade in amber might have been illegal from the perspective of the law, but was certainly considered licit by those involved - state officials included. In fact, local authorities' push for cross-border infrastructural development and increased ties with nearby Kachin state impacted positively the development of the amber trade, rather than jeopardise it. In a similar vein, Eilenberg (2014) shows in the case of the Kalimantan how increased state presence does not necessarily imply the end of illicit economies, in this case Malaysian logging companies, but rather can shield and protect them. Kevin Woods makes a similar point in the case of northern Myanmar, as will be discussed later in this paper, arguing 
that illicit economies flourish not because these remote frontiers are ungoverned and anarchic spaces, but rather because they are embedded in 'ordering' processes where both state and non-state actors play important roles (Woods 2016).

Secondly, the Tengchong case shows how an illegal market comes to be regulated in China. Against simplistic views of the state as the sole maker of rules, the amber case highlights the contextual nature of processes of regulation, involving not only government officials but also private entrepreneurs. Going back to Nordstrom's point, this case is particularly interesting, as the call for official recognition and regulation emerged initially from the traders themselves - the same ones who, for a number of years, enjoyed the benefits of an unregulated flow of amber. If we then follow Baud and van Schendel's (1997) urging to adopt a view from the peripheries to look at borderland communities and cross-border exchanges, the Tengchong case adds another layer of complexity to the ongoing debate on state and market in China. Not only, as argued by Osburg (2013), do Chinese entrepreneurs work deliberately to enmesh business activities into powerful political and social relations, but they also - through those very relations - play an active role in shaping the overall regulatory framework. Furthermore, it is not only states that have the need to perform a double act through which they "pursue their neoliberal dream of a borderless economy and at the same time barricade their borders" (Abraham and van Schendel 2005: 23). Traders, often the same ones who benefited from the lack of regulations in the first place, are also actively involved in the 'barricading' of borders within a new markedly neoliberal border regime. As this paper will describe, in fact, traders involved in the 'illegal' import of Burmese amber came to see the state as an asset, rather than as a threat, and actively worked to bring it into the picture through the institution of the Tengchong Amber Association. Building on the quoted literature on cross-border exchanges, this example further complicates the simplistic notion that contrasts illicit markets and the regulatory efforts of the state.

Furthermore, the on-going process of regulation of the amber market in Tengchong is concurrent to the development of large-scale plans of transnational connectivity, most notably the OBOR initiative. The case at hand shows, on the one hand, the hardening of the border regime that came together with the implementation of such projects. As cross-border trade is generally channelled through a small number of major border crossings for political and economic reasons (Harris 2013), customs inspections and security checks have become more severe (Alff 2016a; 2016b.). On the other hand, however, these same regulations produce an uneven impact across different groups. The case of amber is emblematic. As this paper will show, through the association they created, traders in Tengchong are able to influence local authorities to their advantage. Burmese and smaller scale traders, on the other hand, have become further marginalised in the process. To generalise, an analysis of the cross-border Burmite amber in Tengchong reveals a larger trend. Current 
geo-political initiatives are already producing tangible effects throughout China's border and across it, privileging well-connected, mid- to large-scale enterprises while excluding local and small-scale traders. If border trade is undoubtedly growing, the people and goods moving across these borders are certainly subjected to various - and variable - standards. Considering that China's economic influence in Myanmar and in other countries in the region is likely to further expand as OBOR-led plans are implemented, this should sound as a warning bell that clashes with the 'win-win' rhetoric pervasive in such projects.

\section{BACKGROUND: FROM JADE TO AMBER}

In recent years, China-Myanmar cross-border trade has been dominated by Chinese imports of timber, jade, and raw minerals, often destined for the Chinese luxury market. The jade industry, in particular, has often been at the centre of debates and speculations. With the most important mines situated in Kachin state, jade has played an important role in financing insurgent wars against the Burmese state (Lintner 1999; Chang 2009). As discussed later, the situation started to change with the 1994 ceasefire agreement signed between the Myanmar government and the Kachin Independence Organisation/Army (KIO/A), Myanmar's second largest armed group and the main beneficiary of the jade trade, when the government started to exert greater control over the industry in spite of Western sanctions (Egreteau 2012). A recent investigation conducted by Global Witness (2015) reveals that the Burmese jade industry was worth up to US $\$ 31$ billion in 2014 alone: nearly half the GDP of the whole country.

Trade in Burmese jadeite (known as feicui 翡翠 since the eighteenth century), however, is not a new phenomenon, and has traditionally been of the utmost importance for Tengchong-based traders. By the time of the Ming dynasty, records show that Tengchong was one of the main distributor centres for Burmese jade, and the road to Myitkyina was referred to as the Jade Road (yushi lu 玉石路)' (Gong 1991: 50). While the jade trade and jade carving are still often identified as the city's oldest industries (Li 1991), Tengchong did not manage to preserve its position as Yunnan's main jade trading centre when, following China's opening up and economic growth of the 1980s, the demand for jade steadily increased. The role was, on the other hand, taken by the town of Ruili (Shweli in Burmese), the most important - and for a time, infamous border crossing along the China-Myanmar border (Egreteau 2012).

Compared to Tengchong, Ruili enjoyed a higher degree of openness and lower taxes. The city's main port of entry at Jiegao was set up as a border trade zone by 1990, thus attracting early investments and businesses. Interviews conducted in Tengchong confirm that during the 1990s and early 2000s several hundred Tengchong traders moved to Ruili to work in the jade business, taking advantage of their experience and network of contacts inside Myanmar. 
Since the upgrading of the Houqiao border port in 2004 and the improved conditions of the road to Myitkyina, many of those traders returned to Tengchong and contributed to a significant growth in the local market.

Burmese jade remains today Tengchong's most traded gemstone, yet its share of the gemstone market has shrunk to about 70 per cent, according to local estimates. This downturn reflects a general decline in Chinese demand due mostly to China's economic slowdown. ${ }^{3}$ In Tengchong, however, this decline has corresponded with a sharp increase in Burmese amber imports from nearby Kachin state, which today dominates the remaining 30 per cent of Tengchong's gemstone market. Over the past few years, the amber boom has led to the opening of dozens of amber shops in the city centre, affording remunerative opportunities to thousands of entrepreneurs coming from all over China.

Like jade, Burmese amber is not a completely new product in Tengchong. Burmite was recorded in the 'Records of the unity of the Great Ming' (DaMing yitong zhi 大明一統志), a geographical compendium of the Ming Empire from the fifteenth century. According to Sun (2011), although Chinese sources do not specify the gem, it is likely that amber from Myanmar, together with jade and rubies, appeared in China in the late thirteenth century, if not earlier, and amber (hupo 琥珀) has appeared regularly in Chinese accounts since the fifteenth century. The Tengyue zhouzhi (腾越州志) by Tu Shuliang reports in 1790 that amber, as well as many other precious stones, was originally from Monggong (预拱), not far from today's Myitkyina (1967: 43). The precious gemstone, although increasingly outshined by feicui's growing popularity, also found its way into local legends, demonstrating its wide use and appreciation. One legend in particular tells of a time when, several centuries ago, Tengchong bridges were made of jade and memorial arches were made of amber, as trade in both commodities flourished and brought wealth to the whole city.

Despite this long history, until very recently amber was only available in Tengchong in smaller quantities. Zhang (1993) reports that in the years following 1949, local craftsman could work only with old amber that had been previously brought to Tengchong, as imports sank following the foundation of the PRC. After 1989, a few businessmen from Taiwan and Hong Kong began to purchase some amber in Tengchong, but the high number of fakes and the relatively small demand prevented this particular market from expanding in any significant way. During this period, moreover, Burmite was still very difficult to obtain in significant quantities, and thus Baltic and Caribbean amber came to dominate the market.

\footnotetext{
${ }^{3}$ The decline in jade revenue seems to go beyond Tengchong, and it is confirmed by Burmese data on the trade for 2015 (Kyaw Hsu Mon, Jade Trade: Official Export Earnings Down for 2015, The Irrawaddy, February 16, 2016: http://www.irrawaddy.com/burma/jade-trade-official-export-earnings-down-for-2015.html), a drop that is reportedly having a significant impact on businesses in Myitkyina (Aye Thidar Kyaw and Htin Linn Aung, Shops close as jade prices drop by 70pc in Kachin State, Myanmar Times, November 13, 2015: http://www.mmtimes.com/index.php/business/17620-shops-close-as-jade-prices-drop-by-70pc-in-kachin-state.html).
} 
Starting in the early 2010s, on the other hand, Tengchong traders dealing with antiques (guwan) collected in northern Myanmar started to bring Burmite to China in significant volumes, leading to the boom in imports that this paper addresses. The Li family is often said to be responsible for the initial success of the trade, and interviews with representatives of the family as well as with other traders conducted in Tengchong shed some light on how this success came to happen. According to Li Jian, who is now in his mid-twenties, his family started to buy Burmese antiques in the 1990s. Specifically, they would collect objects from Kachin and Shan groups in northern Myanmar, and sell them in Tengchong. Some of those objects were made with amber, and with time, the Li family was able to expand its network of contacts in both Myanmar and China, buying from different people and selling outside of Tengchong. Still in the late 2000s, very little Burmese amber was imported into China, and even that little amount was passing not through Tengchong, but Laiza, the current capital of the KIO/A, which borders Yingjiang county in Dehong prefecture, only a few hours ride from Tengchong. At that time, Li Jian told us, Kachin traders did not know about the value and market for amber in China, and no Tengchong traders were involved in it. During those years, Li Jian's father began to realise that the demand for amber was growing, as well as its price. As all the dealing in amber was conducted in Yingjiang, Li Jian's father had to drive there three to four times a week in order to purchase amber. Eventually, in exchange for a higher fee, he convinced those traders to move their activities to the Houqiao border crossing, thus bringing the amber trade closer to Tengchong. Still in the late 2000s, as Li Jian recounted, it was only his family and a few buyers in Kunming who were dealing in amber. "We", he told us, "were just like porters (banyungong 搬运工), bringing Burmese amber to Tengchong and from Tengchong to Kunming. Once there, we had no idea how the Kunming traders (keshang 客商) sold the amber" (Interview with Li Jian, 17 February 2016). Around 2009/2010, however, Li Jian stumbled across a website called “Shanghai Wenwan” (上海文玩), where he started selling some of his family's amber. It was a success. Soon after, traders from other parts of China came to Tengchong to purchase amber directly from his family. "And that was it”, Li Jian told us, “everybody saw our family's success (fazhan 发展), and they all started to purchase amber so that when traders came they would have different options. This is how the amber market started off [in Tengchong]" (Interview with Li Jian, 17 February 2016).

\section{Contextualising the Burmite trade boOM: Ceasefire capi- TALISM AND THE ANTI-CORRUPTION CAMPAIGN}

As it emerged from the story of the Li family, a number of circumstances concurred to make Burmese amber an incredibly successful product. Thus, before 
moving into a more detailed description of the current amber market in both Myanmar and Tengchong, it is now opportune to outline some of the political and economic developments that, on both sides of the border, favoured the boom in the Burmite trade.

In Myanmar's Kachin state, most armed groups signed ceasefire agreements with the Burmese government during the early 1990s, putting an end to decades of warfare between ethnic resistance groups, the Chinese-backed Communist Party of Burma (CPB), and the Burmese army. As it has been convincingly argued by Kevin Woods (2011), the ceasefire years granted transnational actors and capital (in this case Chinese) access to natural resources in Kachin state at an unprecedented scale. The timber and mining sectors, in particular, went through an extremely rapid expansion, a development that, paired with a lack of regulations, led to dramatic environmental and social damage (Global Witness 2005; KDNG 2010; Kramer and Woods 2011). Furthermore, the combination of military-state making, capital accumulation, and securitisation in ceasefire areas, which Woods calls 'ceasefire capitalism' (Woods 2011; 2016), contributed to the consolidation of Burmese state power in the resource-rich peripheries of the country. Large-scale resource concessions and the taxing of resource flows and trade, in other words, allowed for a new form of contested territorialisation in the borderlands, a process that eventually led to the resuming of the conflict between the Burmese military and the KIO/A in 2011.

As noted above, the boom in the cross-border amber trade occurred mostly in the post-ceasefire years, as Chinese demand grew significantly only from the early 2010 s. This leads to two significant observations. First, it shows how ceasefire capitalism mechanisms survived the end of the ceasefire itself. As will be described later, the amber mines in Kachin state are within KIO/A-held territory, yet the main nodes of the trade are controlled by the Burmese military. Once again, a combination of interests between Kachin, Burmese, and Chinese elites seems to enable the mining and trading of this particular commodity.

Secondly, while the resumed fighting between the Kachin Independence Army and the Tatmadaw - the official name of the Myanmar armed forces has not affected the trade, the fighting has affected the route through which amber is brought to Tengchong. During the early years of the amber trade, most amber reached Tengchong via Laiza. However, since 2013-14 renewed violence between the Kachin Independence Army and Myanmar forces has diverted most of the traffic to Houqiao, making it by far the most important border crossing in the area. During a visit to the Laiza border crossing in 2016, interviews with local businessmen clearly confirmed that since the conflict restarted, the volume of trade has decreased dramatically, and most traders have left the town.

Furthermore, while Chinese companies have taken advantage of the fragile political situation in northern Myanmar for over two decades, the political climate in Beijing and Kunming seems to have changed recently, as China's main interest has turned to developing infrastructure and regulating cross-border trade with its 
neighbours. The current political situation in northern Myanmar seems to be threatening such investments, raising concerns among many Chinese officials in Yunnan. As the Laiza border-crossing example shows, war is not always good for business. The election of a new government in Myanmar in 2015 and the halting of projects initiated by Chinese companies with the support of the Burmese military have further exacerbated uncertainties among both Chinese officials and local businessmen, who are unwilling to make significant investments without specific assurances. Most dealers in Tengchong agreed that the disorderly (luan 乱) political situation in Myanmar was a major concern, and a negative factor for their own businesses.

There are, however, signals that something in China-Myanmar relations might be changing. The trade in illegal Burmese timber is, in this regard, an interesting indicator. For at least two decades, China has been importing precious timber from nearby Myanmar, causing permanent damage to the local forests (EIA 2015; Woods 2013). Under Myanmar law, the trade is illegal, yet both the government and the military, as well as the KIO/A and other ethnic political groups, have made huge profits from it. Since September 2015, however, all imports of Myanmar timber have been banned by Chinese authorities, and several trips to various border crossings throughout 2016 confirm that very little timber has entered Yunnan since then. ${ }^{4}$ A Chinese government official who spent years overlooking the timber trade in the area explained this decision in the following way:

The end of the timber trade is the Chinese government's decision. The Burmese, in fact, would like to sell us timber, but we don't allow it anymore. The problem is that most of the forests where the timber comes from are in the hands of rebel armies, that then use the money [made from the timber trade] to fund their war against the Burmese government. But now China is trying to build up good relations with the Burmese government. We have several projects at stake: roads, pipelines, dams. We have Chinese companies and workers trying to go there and build all of that infrastructure; lots of money at stake. All of those projects need the support of the Burmese government - they cannot be done without it. That's why we need good relations with the government, not with the rebel armies. It's a long-term strategy, a smarter strategy. (Anonymous Interview, 28 January 2016)

Although the mining business has not yet suffered from a similar fate, the long-term strategy the Chinese government seems to be after would have a significant impact on this sector too. As the next section will describe, amber mines

${ }^{4}$ In November 2016, the Myanmar government declared that it will resume the harvest of aged timber in northern Myanmar according to annually allotted standards, starting in the fiscal year 2017-18. What remains to be seen is to what extend such standards will be respected and what China's role in regulating the flow of timber will be. 
in Kachin state are in close proximity to the old Stilwell Road. If plans for the reconstruction of this important artery are successful, the extraction business and the trade in amber would certainly benefit. On the other hand, this would probably imply a restructuring of the political landscape in Kachin state and an even stronger Tatmadaw presence in the region, something that might exacerbate tensions and lead to further conflicts. China's priorities, however, seem to be clear, and the future of Myanmar's borderlands lies probably as much in Beijing as it does in Naypyidaw.

Another recent policy development within China seems to be having a significant impact on the cross-border trade in luxury goods, thus directly affecting the amber business itself. While indicating that there might be a direct connection between the drop in jade demand and the parallel rise in amber, many amber traders in Tengchong pointed to China's economic slowdown as the main factor behind the jade market's sudden downturn. Others, however, blamed Xi Jinping's anti-corruption campaign. As a Tengchong resident put it, echoing a widespread sentiment:

Xi Jinping is too strict (yan 严); before [the anti-corruption campaign began] people would buy expensive products, jade, timber, to give as presents, to ask favours. But now this is not possible, it's too strict [the anticorruption campaign], and this is dragging the whole economy down. (Anonymous Interview, 1 February 2016)

Compared to jade, amber is traded at a relatively low price, and it thus does not seem to attract too much unwanted attention. Although the connection is not easy to demonstrate, over the past three years, many jade traders in Tengchong have moved part - and in certain cases, most - of their investments into amber, a choice that might reflect the new political climate under Xi Jinping.

To further contribute to the exponential growth of the Burmite market in Tengchong, it is also necessary to consider the increasing Chinese demand for amber as well as the simultaneous near-closure of the famous Fushun amber mines in Liaoning province, which led to a drop in supply and higher prices. Burmite thus became immediately important not only for its quality - it is generally considered better than Fushun amber in both hardness and brightness but also for the available quantity and attractive price. Besides Myanmar, China also imports significant amounts of amber from Russia, Mexico, and Brazil, as well as highly priced Baltic amber from Poland and Lithuania, all for a higher price than Burmite. ${ }^{5}$ In a paper commissioned by the Polish Minister

\footnotetext{
${ }^{5}$ See for instance Anna Sado, The amber boom in China - An interview with Vivian Yang, amber. com.pl, December 31, 2013: http:/www.amber.com.pl/en/news/interviews/item/1962-the-amberboom-in-china-an-interview-with-vivian-yang; Lithuanian amber industry boosted by Chinese market, Xinhua, March 21, 2015: http://news.xinhuanet.com/english/2015-03/21/c_134084966. htm.
} 
of Economy, Chmielowski (2013) estimates that China imports between 40 and 45 tonnes of amber annually, contributing to an overall turnover of about five billion yuan for the Chinese amber market in 2012. If those figures are correct, the impact of Burmese amber on the Chinese market is dramatic. According to interviews with government officials and amber traders, the Tengchong Cultural Industry Office (Tengchong shi zhengfu wenhua chanye bangong$s h i$ 腾冲市政府文化产业办公室) estimated the turnover of the amber trade in Tengchong to be between five and seven billion yuan for the year 2015 alone. As we shall discuss later on, however, the local government's involvement in the amber market is very recent, and this estimate might even be a conservative one.

\section{The amber market in Myitkyina and Tengchong}

The two main nodes on the amber trade route are the towns of Tengchong and Myitkyina, separated by less than $200 \mathrm{~km}$. Located on the western side of the Ayeyarwady River, Myitkyina is a town of about 150,000 people and a 'garrison town' central to the Myanmar government's efforts to control the northernmost parts of the country (Farrelly 2013). Myitkyina, particularly during the ceasefire years, has also been at the centre of the lucrative mining and logging businesses, controlled by a combination of Kachin, Burmese, and Chinese interests. Today, with the rise of Chinese demand and thanks to Myitkyina's proximity to the amber mines, the amber market is becoming increasingly important to the local economy.

Although Ming dynasty gazetteers reported that amber came from Mohying (Mengyang) near the famous jade mines of Hpakant (Sun 2011), Myanmar's main amber mines are in fact located further north in the Hukawng valley, near Danai (Denai 德乃 in Mandarin), a town situated on the old Stillwell Road. The Burmite extracted in the Hukawng valley is at least 100 million years old, and is known for being very clear and harder than other kinds of amber. ${ }^{6}$ Burmite, moreover, can be found in a deep red colour - known as xuepo (血珀), literally 'blood amber' in Mandarin - which is particularly desirable in the Chinese market (Poinar, Buckley, and Brown: 2008). ${ }^{7}$

The Hukawng amber has been known to the Chinese since at least the first century AD (Laufer 1906), and the valley has been Myanmar's main source of

\footnotetext{
${ }^{6}$ Amber from Hukawng made an appearance in the international news in December 2016, when scientists discovered a 99 million year-old dinosaur tail preserved in a piece of amber bought at the Myitkyina market. Kristin Romey, First Dinosaur Tail Found Preserved in Amber, National Geographic, December 8, 2016: http://news.nationalgeographic.com/2016/12/feathered-dinosaurtail-amber-theropod-myanmar-burma-cretaceous/.

${ }^{7}$ Other common varieties of Burmite traded in Tengchong are the so-called 'golden amber' (jinpo 金珀), 'brown amber' (zongpo 棕珀), 'beeswax' (mila 蜜蜡), and 'tea amber' (chapo 茶珀), in addition to rarer pieces containing insects and other prehistoric organisms.
} 
amber for centuries. However, quoting Zherikhin and Ross (2000: 3), this amber represents "the most mysterious varieties of fossil resins in the world". A significant production of amber was first recorded by the Geological Survey of India between 1898 and 1940, showing, however, marked irregularities between different years due probably to the volatile situation in nearby China, but also the possibility for local labourers to work at nearby rubber plantations or jade mines (Zherikhin and Ross 2000; Cruickshank and Ko 2003). At times during this period, in fact, observers recorded little or no activity around the amber mines in Hukawng. After 1947, it appears that the main centre of the amber trade in the valley was abandoned, and the trade almost disappeared. Only with the ceasefire agreement of 1994, mining operations resumed through cooperation between the national government and the KIO/A.

In the 1990s, a Canadian mineral exploration company called Leeward Capital Corp. started to buy Burmite with embedded insects from local miners, reportedly reselling it to customers such as the American Museum of Natural history. Later, Leeward set up a partnership with a local company in Kachin state, and with the support of the KIO/A developed two Burmite mining sites in the Hukawng valley with the aim of mining 500 kilograms of amber per year. ${ }^{8}$ Although it remains unclear to what extend this agreement was successful, interviews conducted in Myitkyina and Tengchong suggest that mining operations did not reach any significant level until the late 2000s, when the trade with China began to gain momentum.

At the time of research, with the renewal of the conflict in Kachin state, it remains unclear to what extend the Tatmadaw exerts direct control over the mines. Chinese traders only go as far as Myitkyina, claiming that it would be too expensive and time consuming to directly visit the mines in the Hukawng valley. On the Burmese side, our interviews suggest that while the Tatmadaw maintains a presence in Danai, the area surrounding the town is at least partly controlled by the $\mathrm{KIO} / \mathrm{A}$, which also seems to control the amber mines. Until recently, the jade mines in Hpakant, which have been the subject of much more research, were known to be managed by a commonality of interests between the Burmese army and the KIA (Chang 2011). Most of our interviewees in Myitkyina suggested a similar pattern for the amber mines in Hukawng. We were not able, however, to find any definitive answer on the issue. Amber, moreover, does not appear as a separate category in the recent EITI report (2015), highlighting not only the lack of official data on the industry, but also how Burmite is not yet on the international radar when it comes to the discussion of Burmese resource extraction.

${ }^{8}$ Lisa Dempster, Amber exporter hails Myanmar 'evolution', Business Edge News Magazine, August 10, 2003: http://www.businessedge.ca/archives/article.cfm/amber-exporter-hails-myanmar-evolution-3760. 
In Myitkyina, however, the amber business is already having a significant impact on the local economy. Every day, several hundred local dealers gather at the Gems and Jewellery Trade Centre at the northern edge of town. The centre was inaugurated in 2014, and consists of a few dozen shops selling highend stones, and a lively open-air market mostly displaying amber in raw form. Local sellers confirm that virtually all of the amber goes to China, although at times some European buyers purchase a few pieces. On the other side of the Ayeyarwady, another small industry has grown out of the amber market. In the village of Waimaw, a number of local Kachin set up polishing and carving businesses in their houses. Working with machines imported from China, they carve round pieces for bracelets and necklaces. Most carvers buy the amber directly from Danai traders or miners, and then sell their products either to middlemen at the Myitkyina centre, or in Tengchong where they regularly travel to themselves. Many of those carvers used to work in the jade business, but recently moved to amber as it has become more lucrative. As confirmed by various residents of Waimaw, this new business has brought significant wealth to many in the village, and a number of new two-storey houses have sprung up as a consequence.

There are different ways through which Myanmar amber arrives in Tengchong. For the most part, Burmese traders, often working in small groups of two to four people, bring the amber to Tengchong and, once there, sell it to Chinese dealers. Only a few sell it directly to customers in the market. There are several reasons for this. First, there is the language barrier. Many Burmese speak only limited Mandarin, and for them it is easier to deal with Chinese amber dealers who, at times, have learned some Burmese themselves, and most importantly have a better understanding of the product and do not need any introduction. Usually, in those cases, Burmese traders visit various amber shops in Tengchong, show the products they have brought, and listen to the Chinese dealer's offer. If the offer is not satisfying, they simply move on to another shop. The process usually does not take more than a few minutes. In this way, moreover, Burmese dealers are able to create a network of contacts that can be helpful for their business. Many, in fact, are able to come and spend longer periods of time in Tengchong only after being formally invited by some Chinese dealers. Secondly, by selling to Chinese dealers, Burmese traders are able to sell larger quantities of amber, often in raw form. Given the low quality of Burmese carving, most Tengchong dealers prefer to buy amber in this form, and then have it carved there.

As already shown in the example of the Li family, Burmese traders can at times purchase amber in Myanmar on account of Chinese dealers based in Tengchong. This practise does not seem to be particularly common today, partly because such arrangements require a level of trust that is often difficult to establish. Tengchong traders, moreover, are quite reluctant to employ Burmese dealers working on credit, and rather prefer to purchase the amber directly. Most importantly, with the growing number of Burmese dealers travelling 
directly to Tengchong to sell their amber, there is little convenience in entering into a risky arrangement such as this.

A few Chinese dealers also travel to Myanmar to purchase the amber. This practise also does not seem to be particularly common. First, Chinese dealers are for the most part unable to travel directly to the amber mines in Danai. Some areas around the remote location remain largely outside of the control of the Myanmar government, and foreign nationals are generally banned from travelling there on the base of security concerns. Various Chinese dealers in Tengchong also suggested that making the trip would require paying off various groups along the way, thus making it unprofitable. For Chinese amber dealers then, the main centre inside Myanmar is Myitkyina, and in particular, the Gems and Jewellery Trade Centre. Contrary to what one might think, however, amber prices at the Myitkyina market are often higher than in Tengchong, as most amber seems to go directly to China. Many dealers in Tengchong reported that Burmese traders, when not satisfied with the prices in Tengchong, often travel back to Myitkyina and sell their products there at a higher price. For Chinese dealers then, the Myitkyina market does not seem to always represent an attractive option. Besides the price of the amber, the transportation costs are also to be considered, not to mention the risk of being caught smuggling amber into China at the border.

On the Chinese side, Tengchong virtually monopolises the Myanmar amber trade - with Ruili coming in a distant second. According to local estimates, over 10,000 people are currently directly or indirectly engaged in the amber industry in Tengchong, with around 2000 people specialising only in amber. ${ }^{9}$ Considering that only a few years ago the amber industry in Tengchong simply did not exist, these numbers are astonishing. This figure also includes about 1000 Burmese involved in the amber business in Tengchong, as well as 700 carvers and polishers. The latter group of people is mostly made up of outsiders originally from Fujian, Guangdong, Henan, Guangxi and the northeast, many of whom have previous experience in the jade industry. Most of the carving occurs in little hole-inthe-wall workshops in the vicinity of the biggest amber shops.

In Tengchong, the main area for the amber trade is called Trade and Commerce City (shangmao cheng 商贸城), with most high-end shops facing nearby Jianhua Road (建华路), close to the centre of the city. Originally built as a market for all sorts of daily products, Trade and Commerce City has been dominated by amber and (to a lesser extend) jade dealers since the early 2010 s. Of the various shops, only between one third and one quarter are owned by Tengchong families. The other shops have been opened by entrepreneurs coming from other parts of China. A significant number of them are originally from the northeastern part of the country and used to work with Fushun amber before the mines in

\footnotetext{
${ }^{9}$ This estimate was the result of a meeting between Tengchong's main amber dealers and local government officials, which we shall discuss further later on.
} 
Liaoning closed down. They are often admired by Tengchong amber dealers for their hard work and resourceful attitudes toward the business. Tengchong dealers, by their own admission, prefer to stay in Tengchong and conduct their business from there. Outsiders, however, "run around the whole country" (quanguo pao 全国跑) to sell the amber they purchase in Tengchong, while local traders are a bit too “comfortable” (anyi 安逸) (Anonymous interview, 31 January 2016).

Besides the many shops, the area also hosts a jewellery market (zhubao jie 珠宝街) that takes place every five days and attracts large numbers of people. During several visits in 2016, we observed that the market had an average of 1200 stalls. Most of them (around 70 per cent) sell feicui while the rest sell amber, with only a few dozen stalls selling huanglong jade, shuimo jade, and manao (a red stone from nearby Baoshan that appears in early Qing dynasty accounts (Sun 2011) but that never managed to gain wide popularity). Of the various sections of the open-air market, however, the amber section was always the most crowded. It was also the section with the most Burmese sellers, a good half of the total.

The jewellery market is collectively managed by traders from the Trade and Commerce City, who are in charge of collecting the fee for each booth (tanwei 推位), amounting to an average of 80 yuan per day (approximately 12 US dollars), which is then used to pay for services such as water and electricity. There are, however, a number of exceptions, with booths placed in front of private shops not paying any rent, and other clusters of booths managed by a single entrepreneur. Often those booths are given free of charge, in exchange for a percentage of the day's sales.

From Tengchong, amber is also sold throughout the country in a number of different ways. First, amber dealers have shops where they sell both at retail - to single customers - and wholesale - to other dealers, often coming from other parts of China. Many have established networks of contacts outside of Tengchong, and trusted partners in different locations throughout the country. As already mentioned, Tengchong dealers rarely leave town, often only to attend fairs or specific gemstone-related events in other parts of the country. Outside traders, however, are more likely to travel and sell their amber in major cities such as Beijing, Shanghai, and Guangzhou. With Tengchong's growing tourist industry, the government has also been very supportive of the gemstone market, and many have opened shops in the vicinity of the most popular tourist attractions, such as the 'Anti-Japanese War Memorial Hall'.

Some amber is also sold online through various websites specialising in gemstones and antiques. Most recently, however, the online market for amber has been largely taken over by WeChat, China's most popular social network and messaging app. WeChat also supports payment and money transfer through a service called "WeChat Payment", which allows users to make user-to-user transfers. Given the popularity of online shopping in China, WeChat Payment has led 
to the appearance of a particular kind of dealer, known in Mandarin as weishang (微商), selling products only through WeChat. In Tengchong, most amber dealers do not engage directly in this. However, many weishang regularly visit amber shops where they enquire about prices and take pictures of specific objects and stones, which they then share on their WeChat account. They thus function as middlemen, selling Tengchong amber to buyers from all over the country.

Those different ways of dealing amber are not mutually exclusive. On the contrary, often Tengchong dealers employ a combination of strategies and work with different actors on both sides of the border. Furthermore, compared to the jade market, Burmese dealers play a much more important role. Although few own businesses in Tengchong, the overwhelming majority of the amber is brought into China by Burmese traders, who then sell it to Chinese dealers in town making a significant profit for themselves. Amber, moreover, is "always changing hands", as we were repeatedly told in Tengchong. Dealers in town often buy amber from one another, and it is not rare for a single piece of amber to be sold several times among Tengchong-based dealers before finding its way to a different market. Partly, this is due to the uniqueness of each piece of amber, which affords opportunities for the trained eye, and, in fact, the ability to spot undervalued pieces at the market in Tengchong can lead to significant profits. Moreover, amber and gemstones in general are seen as solid investments in China, and thus dealers buy whenever they can find a good opportunity.

\section{Regulating the amber market in Tengchong}

The bulk of the amber trade occurs outside of the regulatory regime, as amber rarely - if ever-goes through either Chinese or Burmese customs at the border. As Li Jian put it: "If amber were to go through customs it would not be profitable. We sell amber by the gram. I heard that customs tax is around 40 yuan/gram, more than the price of a gram of most amber you find in Tengchong!" (Interview with Li Jian, 17 February 2016). For this reason, it is impossible to say with certainty how much amber is currently imported to China via Tengchong. Local estimates for the year 2015, taken from both amber dealers and Chinese border officials at Houqiao, put it at around 100 tonnes. This figure, however, remains purely indicative.

This does not mean, however, that the Tengchong government is not trying to regulate the amber market. Yet given the sudden success of Burmese amber, measures to keep the trade under control have only recently begun to be put in place. Quite significantly, however, it was not local officials but the amber dealers themselves who initially pushed for a more regulated market and increased collaboration with authorities. Those efforts culminated with the creation of the Tengchong Amber Association (Tengchong shi hupo xiehui 腾冲市琥 
珀协会) in January 2016, at a meeting in a five-star hotel in Tengchong. In the course of our research, we were not only able to interview some of the over 60 traders and government officials who participated to the first meeting of the Association, but we were also given access to the official report that was produced following the meeting. The report outlines the regulation guidelines for the Association and a complete list of its members. This section is mostly based on this report and on interviews conducted with members of the newly formed Association.

Given the success of the trade, the Tengchong government recently listed amber as one of the city's main eight industries, and put its management under the responsibility of the Tengchong Cultural Industry Office. Authorities in Tengchong are well aware that Burmese amber reaches Tengchong via illicit channels, without going through customs at Houqiao or any other port of entry. The trade, however, has largely been tolerated, although stories of amber being seized along the Houqiao-Tengchong route circulate in the main gemstone market in Tengchong. Li Jian put it in the following way: "Custom officials can confiscate [amber], they carry out inspections and can also set up mobile check-points. But it doesn't happen very often. [...] The majority of the vehicles carrying amber make it to Tengchong, more than 90\%; very few are seized" (Interview with Li Jian, 17 February 2016). According to many traders, moreover, seized amber can be easily bought back from corrupt custom officials, and thus ends up at the Tengchong market anyway. Once there, we were repeatedly told, the amber is considered legal, and nobody can seize it. All the risks, then, are limited to the few kilometres between Houqiao and Tengchong.

This apparent ambiguity between the illicit means through which amber is brought into China, and the legal ways through which it is traded once in Tengchong, is one of the main reasons behind the traders' effort to set up the Tengchong Amber Association. Virtually all of the traders we interviewed were hopeful that through the Association, amber traders and government officials would come to an agreement over the taxation of amber that would be favourable for business, and ensure that no further seizures would occur and more investments would be made - and most importantly, that the government would represent their interests to the Association's counterpart(s) in Myanmar. In the language of much economic discourse in today's China, traders in Tengchong are thus hoping for a mutually beneficial (gongying 共赢) outcome.

The report of the first meeting of the Association contains a first draft of the Association's constitution, an outline of the voting system for the members, and a list of its current members. The document establishes the Association as a nonprofit entity, whose purpose is to foster unity (tuanjie 团结), communication (jiaoliu 交流), trust (chengxin 诚信), and development (fazhan 发展) between the government and members of the Association, thus acting as an intermediary between officials and traders. Accordingly, the Association is in charge of delivering and discussing new government policies with the members, keeping the price 
of amber stable, ensuring the absence of fake amber from the market (as part of the Association's regulations, if a member sells fake amber he or she would have to compensate the cheated costumers for ten times the price spent), representing the members' interests at the government level, mediating disputes among members, and guaranteeing the fairness of the trade (gongping jiaoyi 公平交易). Members, on the other hand, must subscribe to the Association's rules and pay membership dues according to their rank.

Despite its only recent appearance and the vagueness of certain critical points, none of the traders we interviewed in Tengchong underestimated the impact that the Association would have on the amber trade. The general impression among those involved with the Association was that, with time, traders and the government would reach an agreement based on the following two pillars: a low custom tax on amber which traders would commit to pay in exchange for government support and investments. No one, however, would venture into providing more details, insisting that the actual content of the accord was to be worked out within the Association over the following months and years. The overall impression, moreover, was that for Tengchong traders the Association was less about regulating the imports of amber in order to avoid its seizure by border patrol forces, and more about providing them with a way to shape how government policies regarding amber are drafted and carried out. To be sure, traders were confident that having the government on their side would be of significant help in cases of conflicts with their Burmese counterparts or Myanmar authorities. The creation of the Association was then a way, for traders, to bring the state in, but also to ensure that the amber trade would be dealt with according to their own interests.

Thus far the creation of the Association does not seem to have had any significant impact on the way amber is brought into Tengchong. For the most part, the actual import of amber through Houqiao remains in the hands of individuals or small groups of Burmese dealers, who generally take all of the risks. Many Tengchong traders often pointed out to us that there is so much amber coming into Tengchong via these channels, that they generally only have to sit tight and wait for somebody with a good deal to walk through their shop's doors. Paired with the mining operations in the Hukawng valley, which remain in Burmese hands, the case of the amber trade in Tengchong thus seems to resemble what Anna Tsing has called 'supply chain capitalism' (2015). Miners in Hukawang and small-scale Burmese dealers bringing amber to Tengchong, in other words, whilst being an integral part of this specific supply chain, remain largely outside of any form of capitalist accumulation. Tengchong-based traders, on the other hand, work from within a system of accumulation bounded by state regulations they themselves collaborate in creating. As Tsing asserted, there is salvage accumulation on the one hand - illegal, risky, and unrepresented - and capitalist accumulation on the other - in which the state and traders come together to define the market for a particular commodity (Tsing 2005; 2015). 
The Tengchong Amber Association, moreover, seems to have been created with the implicit goal of promoting the interests of a specific group of Tengchong amber traders: the wealthiest ones. As mentioned above, each member of the Association is required to pay a fee in order to be part of it. While the fee for a regular membership is not high, the president of the Association (currently Yang Chenguang, a major trader from Fujian) paid 200,000 RMB (US\$ 29,000), and the vice-President (Lin Shengyao, a local businessman) 100,000 RMB (US\$14,500) for the first year. When asked about why would someone pay such a high fee for these positions, the answer was "fame and wealth (mingli 名利)", in particular through the chance to establish closer ties with the government.

To be sure, going back to the point made in the first section of this paper, the constitution of the Association seems to reflect a larger trend as part of which large-scale traders benefit from close ties with the local government, while small to mid-size trading enterprises suffer as their interests remain unrepresented. Burmese dealers, despite their fundamental role in the amber supply chain, are ultimately replaceable and thus stand at the lowest end of the spectrum, and are not even allowed to join the Association. To put it in different words, while the border regime at the China-Myanmar border has certainly hardened, this hardening does not operate evenly across different groups of traders. As a result, some have been further marginalised, while others have been included in the regulating process while, at the same time, profiting from the illicit practices they are supposedly regulating. Contrary to repeated claims of open borders and free markets so embedded within the OBOR vision, what the case of the Tengchong Amber Association shows is that proximity to the state seems to be, still, the main guarantee of success in China's borderlands.

At this stage, however, it is not possible to venture into further conclusions and analysis. The process of regulating the amber market has just begun, frictions are likely to arise, and competing interests are bound to emerge among members of the Association. The risk that some traders highlighted is that the costs of transporting amber into China will increase due to custom taxes. This would lead to higher prices for Burmese amber in a market that has already reached a point of quasi saturation, and the possible exclusion of many actors (mostly Burmese) from the trade due to their weaker financial position. It is even possible, then, that a significant part of the trade will be pushed further into illegality, thus generating conflicts between traders and local authorities, or between a complacent local government and stricter officials from Kunming and Beijing.

\section{Conclusion: PROBlems AND PERSPECTIVES}

In the narrow alleys of Tengchong's amber market, a few stalls sell fruits and vegetables. A common joke among local residents is that those are the most 
expensive vegetables in Tengchong. Amber dealers, the main customers, make so much money out of their trade that they cannot be bothered to bargain the price or look for cheaper alternatives. As the joke clearly suggests, amber has brought a new wave of wealth to many gemstone dealers in Tengchong, and to the town as a whole. While during our interviews most traders seemed to share the optimism of local authorities regarding the future of the business, a few issues that threaten to jeopardise the amber trade also need to be taken into account.

Besides the on-going regulation of the market discussed in the previous section, another liability lies in the fact that the entire amber market in Tengchong is driven by internal demand. With a worrying economic slowdown and the persistence of the anti-corruption campaign, demand for Burmese amber is likely to curb over the next few years. Amber prices, moreover, reached a peak in 2015 , and many traders lament that the market is already over saturated. As a sarcastic local scholar in Tengchong told us, the whole amber industry might be just one of many Chinese fads (chaozuo 炒作) destined to go away just as fast as it appeared (Anonymous interview, 21 January 2016).

On the other side of the border, problems are of a different nature, as the future of Myanmar's political landscape remains uncertain. A nationwide ceasefire agreement is still under negotiation and the possibilities of further conflicts remain a realistic threat. Moreover, following Aung San Suu Kyi's National League for Democracy (NLD) landslide victory in November 2015, at the time of research Chinese officials were still unsure about the new government's policy toward China, and many contracts for Chinese-funded infrastructure were under renegotiation. These are all factors that will, in one way or another, have a significant impact on cross-border trade, amber included.

It is also important to add the issue of labour conditions in Myanmar's amber mines to this discussion, which remain a source of concern together with the environmental impact of the industry. Although there is not any direct analysis of labour conditions in the Hukawng valley amber mines, which remain out of reach for external observers, horrific reports on the conditions in jade mines in nearby Hpakant and the gold mines in the Hukawng valley (KDNG 2007) raise a number of important questions. With Myanmar's on-going process of democratisation and opening up to foreign investment, the lucrative industry might come under scrutiny over safety, ethical, and environmental issues.

To what extend these various challenges might hurt the trade in Burmite, it is still too early to say, and further research, particularly inside Myanmar, is needed. However, returning to the question of shadow economies, and the state and market in China, we offer the following concluding thought. While in the West there has been a recognisable tendency to fetishize the market as an abstract and homogenising force, anthropologists have argued for the need to empirically investigate how markets are constructed in specific cultural and historical contexts, and within networks of often pre-existing social and kinship relations (Ho 2005; Zaloom 2006). Similar attention, we argue, should be extended to China 
when it comes to the analysis of the state, too often simplistically regarded as a monolithic and omnipresent entity. As this paper has shown, even practices that are generally considered to be monopolised by the state, such as legislation, are in fact emerging out of contested processes in which state, non-state, and even 'shadowy' actors participate. Although in the specific case of the amber trade, it is still too early to draw any definitive conclusion, theoretically or otherwise, the distinct impression we gathered from Tengchong is that small-scale actors are becoming increasingly marginalised, while well-connected businesses are prospering. If this is the direction the One Belt, One Road Initiative is headed in, then it is worthwhile for anthropologists to analyse these processes from within specific practices and culturally specific locales such as those we have described in this paper.

\section{Acknowledgments}

Research for this article was conducted with the generous support of the European Research Council (Starting Grant 637764, Highland Connections). The authors would like to thank Martin Saxer, Judd Kinzley, Gang Chen and the anonymous reviewers for their insightful comments on various versions of this article.

\section{References}

Abraham, Itty, and Willem van Schendel, eds. 2005. Illicit Flows and Criminal Things: States, Borders, and the Other Side of Globalization. Bloomington: Indiana University Press.

Alff, Henryk. 2016a. "Getting stuck within flows: limited interaction and peripheralisation at the Kazakhstan-China Border." Central Asian Survey 35(3): 369-86.

Alff, Henryk. 2016b. "Flowing goods, hardening Borders? China’s commercial expansion into Kyrgyzstan re-examined." Eurasian Geography and Economics 57(3): 433-56.

Alff, Henryk. 2016c. "Trading on Change: Bazaars and Social Transformation in the Borderlands of Kazakhstan, Kyrgyzstan and Xinjiang." In The Art of Neighbouring: Making Relations Across China's Borders, edited by Martin Saxer and Juan Zhang, 95-119. Amsterdam: Amsterdam University Press.

Baud, Michiel, and Willem van Schendel. 1997. "Toward a comparative history of borderlands." Journal of World History 8(2): 211-242.

Bruns, Bettina, and Judith Migglebrink, eds. 2012. Subverting Borders: Doing Research on Smuggling and Small-Scale Trade. Wiesbaden: VS Verlag.

Chang, Wen-chin. 2009. "Venturing into 'barbarous' regions: transborder trade among migrant Yunnanese between Thailand and Burma, 1960s-1980s." Journal of Asian Studies 68(2): 543-72.

Chmielowski, Pawel. 2013. Amber jewellery market in China, Trade and Investment Promotion Section, Embassy of Poland in China. Available at: https://china.trade.gov.pl/ pl/f/download/fobject_id:247458 (accessed 10 April 2017). 
Chouvy, Pierre-Arnaud, ed. 2013. An Atlas of Trafficking in Southeast Asia: The Illegal Trade in Arms, Drugs, People, Counterfeit Goods and Natural Resources in Mainland Southeast Asia. London and New York: I. B. Tauris.

Cruickshank, R. D., and Ko Ko. 2003. "Geology of an amber locality in the Hukawng Valley, northern Myanmar." Journal of Asian Earth Sciences 21(5): 441-455.

Egreteau, Renaud. 2012. "The Burmese Jade Trail: Transnational Networks, China, and the (Relative) Impact of International Sanctions on Myanmar's Gems." In Myanmar's Transition: Openings, Obstacles and Opportunities, edited by Nick Cheesman, Monique Skidmore, and Trevor Wilson, 89-116. Singapore: Institute of Southeast Asian Studies.

Eilenberg, Michael. 2014. "Frontier constellations: agrarian expansion and sovereignty on the Indonesian-Malaysian border.” The Journal of Peasant Studies 41(2): 157182.

Eilenberg, Michael, and Reed L. Wadley. 2009. "Borderland livelihood strategies: the socio-economic significance of ethnicity in cross-border labour migration, West Kalimantan, Indonesia." Asia-Pacific Viewpoint 50(1): 58-73.

Environmental Investigation Agency (EIA). 2015. Organised Chaos: The illicit overland timber trade between Myanmar and China. London: Environmental Investigation Agency.

Fang, I-Chieh. 2010. “'Talking' landscape: the culture dynamics of Rushang (Confucian entrepreneurs) in a peripheral migrant hometown in Yunnan.” The Asia Pacific Journal of Anthropology 11(2): 191-204.

Farrelly, Nicholas. 2013. "Nodes of Control in a South(east) Asian Borderland." In Borderland Lives in Northern South Asia, edited by David Gellner, 194-213. Durham and London: Duke University Press.

Galemba, Rebecca. 2013. "Illegality and invisibility at margins and borders." PoLAR 36 (2): 274-285.

Global Witness. 2005. A choice for China: ending the destruction of Burma's northern frontier forests. London, UK.

Global Witness. 2015. Jade: Myanmar's 'Big State Secret'. London, UK.

Gong, Zijun. 1991. “Tengchong zhubao ye.” In Tengchong wenshi ziliao xuanji, edited by Wenhe Yin, and Zhaoming Ma, 50-56. Tengchong: Tengchong county CPPCC literature and history division committee.

Gootenberg, Paul. 2005. "Talking Like a State: Drugs, Borders, and the Language of Control." In Illicit Flows and Criminal Things: States, Borders, and the Other Side of Globalization, edited by Willem van Schendel and Itty Abraham, 101-127. Bloomington: Indiana University Press.

Harris, Tina. 2013. "Trading places: new economic geographies across Himalayan borderlands.” Political Geography 35: 60-68.

Ho, Karen. 2005. "Situating global capitalisms: a view from Wall Street investment banks." Cultural Anthropology 20(1): 68-96.

Kachin Development Networking Group (KDNG). 2007. Valley of Darkness: Gold Mining and Militarization in Burma's Hugawng Valley. Chiang Mai, Thailand: Kachin Development Networking Group.

Kachin Development Networking Group (KDNG). 2010. Tyrants, Tycoons and Tigers: Yuzana Company Ravages Burma's Hugawng Valley. Chiang Mai, Thailand: Kachin Development Networking Group.

Kramer, Tom, and Kevin Woods. 2011. The Political Economy of Northern Burma: Chinese Investment, Alternative Development and Dispossession. The Netherlands: Transnational Institute. 
Kudo, Toshihiro. 2008. "Myanmar’s Economic Relations with China: Who Benefits and Who Pays?" In Dictatorship, Disorder and Decline in Myanmar, edited by Monique Skidmore, and Trevor Wilson, 87-109. Canberra, Australia: The Australian National University E Press.

Kudo, Toshihiro. 2010. "Myanmar's Border Trade with China: Situation, Challenges and Prospects." In Economic Relations of China, Japan and Korea with the Mekong River Basin Countries, edited by Mitsuhiro Kagami, 266-294. Bangkok, Thailand: Bangkok Research Center.

Laufer, Berthold. 1906. "Historical jottings on amber in Asia." Memoirs of the American Anthropological Association, 1(3): 215-244.

Li, Hexing. 1991. "Tengchong feicui yudiaoye fazhan chu tan.” In Tengchong Wenshi Ziliao Xanji, edited by Wenhe Yin, and Zhaoming Ma, 61-73. Tengchong: Tengchong county CPPCC literature and history division committee.

Lintner, Bertil. 1999. Burma in Revolt: Opium and Insurgency Since 1948. Chiang Mai: Silkworm Books.

Lintner, Bertil. 2011 [1990]. Land of Jade: A Journey from India through Northern Burma to China. Bangkok: Orchid Press.

Myanmar Extractive Industries Transparency Initiative (EITI). 2015. EITI Report for the period April 2013-March 2014: Oil, Gas and Mining Sectors. Yangon: Myanmar Extractive Industries Transparency Initiative.

Nordstrom, Carolyn. 2000. "Shadows and sovereigns." Theory, Culture and Society 17 (4): $35-54$.

Osburg, John. 2013. "Global capitalisms in Asia: beyond state and market in China." The Journal of Asian Studies 72(4): 1-17.

Poinar, George.Jr., Ron Buckley, and Alex E. Brown. 2008. "Secrets of Burmite amber." MAPS Digest 20: 21-29.

Saxer, Martin. 2009. "Herbs and traders in transit: border regimes and the contemporary trans-Himalayan trade in Tibetan medicinal plants." Asian Medicine 5(2): 317-339.

Saxer, Martin. 2016. "New Roads, Old Trade: Neighbouring China in Nepal." In The Art of Neighbouring: Making Relations Across China’s Borders, edited by Martin Saxer and Juan Zhang, 73-92. Amsterdam: Amsterdam University Press.

Schneider, Friedrich, and Dominik H. Enste. 2002. The Shadow Economy. Cambridge: Cambridge University Press.

Schoenberger, Laura, and Sarah Turner. 2009. "Negotiating remote borderland access: small-scale trade on the Vietnam-China border." Development and Change 39(4): $667-696$.

Spengen, Wim van. 2000. Tibetan Border Worlds: A Geohistorical Analysis of Trade and Traders. New York: Kegan Paul International.

Steenberg, Rune. 2014. "Network or community? Two tropes for analysing social relations among Uyghur traders in Kyrgyzstan." Crossroads Asia Working Paper Series, No. 18.

Sun, Laichen. 2011. "From Baoshi to Feicui: Qing-Burmese Gem Trade, c. 1644-1800." In Chinese Circulations: Capital, Commodities, and Networks in Southeast Asia, edited by Eric Tagliacozzo and Wen-chin Chang, 203-220. Durham and London: Duke University Press.

To, Phuc Xuan, Sango Mahanty, and Wolfram Dressler. 2014. "Social networks of corruption in the Vietnamese and Lao cross-border timber trade." Anthropological Forum 24(2): 154-174.

Tsing, Anna. 2005. Friction: An Ethnography of Global Connections. Princeton and Oxford: Princeton University Press. 
Tsing, Anna. 2015. The Mushroom at the End of the World: On the Possibility of Life in Capitalist Ruins. Princeton and Oxford: Princeton University Press.

Tu, Shuliang. 1967. Tengyue Zhouzhi. Taibei: Chengwen chubanshe.

Winichakul, Thongchai. 1994. Siam Mapped: A History of the Geo-Body of a Nation. Honolulu: Hawaii University Press.

Woods, Kevin. 2011. "Ceasefire capitalism: military-private partnership, resource concessions and military-state building in the Burma-China borderlands." The Journal of Peasant Studies 38(4): 747-770.

Woods, Kevin. 2013. Analysis of China-Myanmar timber trade. Forest Trends Policy Brief. Washington, DC: Forest Trends, available at: http://www.forest-trends.org/ documents/files/doc_4775.pdf (accessed 10 April 2017).

Woods, Kevin. 2016. "The Commercialisation of Counterinsurgency: Battlefield Enemies, Business Bedfellows in Kachin State, Burma." In War and Peace in the Borderlands of Myanmar: The Kachin Ceasefire, 1994-2011, edited by Mandy Sadan, 114-146. Copenhagen: NIAS Press.

Yin, Wenhe, and Zhaoming Ma, eds. 1991. Tengchong Wenshi Ziliao Xuanji. Tengchong: Tengchong county CPPCC literature and history division committee.

Zaloom, Caitlin. 2006. Out of the Pits: Traders and Technology from Chicago to London. Chicago: Chicago University Press.

Zhang, Zhubang. 1993. "Tengchong de hupo gongyi (Amber handicraft in Tengchong)." China Lapidary 5(4): 38-40.

Zherikhin, V. V., and Andrew J. Ross. 2000. "A review of the history, geology and age of Burmese amber (Burmite)." Bulletin of the Natural History Museum, London (Geology) 56(1): 3-10.

Zhou, Yongmin. 2013. "Branding Tengchong: Globalization, Road Building, and Spatial Reconfigurations in Yunnan, Southwest China." In Cultural Heritage Politics in China, edited by Tami Blumenfield and Helaine Silverman, 247-260. New York: Springer.

\section{Interviews}

Anonymous interview with Tengchong CCP official, 28 January 2016, Tengchong, China. Anonymous interview with representative of the Tengchong Hongyida company, 30 January 2016, Houqiao, China.

Anonymous interview with Tengchong amber trader, 31 January 2016, Tengchong, China.

Anonymous interview with Tengchong-based amber trader, 1 February 2016, Tengchong, China.

Anonymous interview with Tengchong-based scholar, 21 February 2016, Tengchong, China.

Interview with Li Jian, 17 February 2016, Tengchong, China. 